\title{
Judicial review and the protection of privacy rights in dawn raids
}

\author{
Nima Lorjé* and Ariela Stoffer+
}

\begin{abstract}
Commission inspections pursuant to Article 20(4) of Regulation 1/2003 (i.e. dawn raids) interfere with the privacy rights of companies and individuals. This interference is disproportionate when it is not consistent with the requirements laid down in Article 7 of the Charter of Fundamental Rights of the European Union and Article 8 of the European Convention for Human Rights. In its recent judgments in the French Supermarkets cases, the General Court partially annulled four Commission inspection decisions for constituting an arbitrary and unjustified interference with the privacy rights of the inspected companies. The General Court found that the Commission had initiated inspections without having sufficiently serious evidence in its possession. This article examines this finding of the General Court and its practical implications for the protection of companies' privacy rights in the context of dawn raids. In addition, this article examines possible remedies for challenging the seizure and copying of documents containing personal information of raided companies' staff during a dawn raid.
\end{abstract}

Keywords: dawn raids, inspection decisions, privacy rights, rights of defence, sufficiently serious indicia of suspected infringement, power to seize documents, Regulation 1/2003, European Commission

\section{Introduction}

The European Union courts have repeatedly confirmed the wide investigatory powers of the European Commission (Commission) in competition cases. At the same time, there is a gradually growing body of case law in which the European Union courts have recognized that fundamental rights, in particular the right to privacy, limit the powers of the Commission to conduct unannounced site inspections (also referred to as 'dawn raids') under Articles 20 and 21 of Regulation $1 / 2003 .^{1}$ On 5 October 2020, the General Court of the European Union (General Court) handed down three judgments, ${ }^{2}$ which build upon this body of case law. In these noteworthy judgments, the General Court partially annulled the Commission's inspection decisions to raid several French supermarkets, as it found that the dawn raids constituted a disproportionate interference with the right to privacy of those French supermarket chains. In addition, these judgments open the door for raided companies to claim protection against the seizure of documents concerning the private lives of their managers and employees.

\footnotetext{
Associate Partner, Competition, NautaDutilh, Amsterdam.

Associate General Counsel and Data Privacy Counsel, JBT Corporation, Amsterdam.

1 Council Regulation (EC) 1/2003 on the implementation of the rules on competition laid down in Articles 81 and 82 of the Treaty [2003] O.J. L $1 / 25$.
}

This article will examine how the General Court applied the right to privacy in the French supermarkets cases, in order to provide practical guidance on how the right to privacy can be invoked to protect the interests of companies subject to inspections.

Section 2 of this article provides a brief and general overview of the case law of the European Union courts on the application of the right to privacy in the context of competition cases. Section 3 examines the main findings of the General Court in the French supermarkets cases. Section 4 summarizes the practical significance of these judgments for companies and legal practitioners dealing with dawn raids. Finally, Section 5 lays out a couple of further considerations.

\section{Privacy rights in EU competition cases}

\subsection{The right to privacy of raided companies}

Under Article 20(4) of Regulation 1/2003, the Commission has the power to adopt decisions to conduct unannounced

2 Case T-249/17 Casino Guichard-Perrachon, Achats Marchandises Casino SAS v. Commission EU:T:2020:458; Case T-254/17 Intermarché Casino Achats v. Commission EU:T:2020:459 and Case T-255/17 Les Mousquetaires and ITM Entreprises v. Commission, EU:T:2020:460 
inspections at business premises of companies suspected of infringing competition law. This power must be applied in compliance with the fundamental rights and principles recognized by EU law, in particular by the Charter of Fundamental Rights of the European Union (the Charter). ${ }^{3}$ This includes the right to respect for private life, family life, home and communications as enshrined in Article 7 of the Charter, also generally referred to as the right to privacy'. ${ }^{4}$ Article 7 corresponds ${ }^{5}$ to Article 8 of the European Convention of Human Rights (ECHR). According to Article 52(3) of the Charter, the scope and the meaning of the two provisions are the same, albeit more extensive protection may be provided under EU law. The essential purpose of the right to privacy is to protect individuals and companies from arbitrary interference in their spheres of privacy. ${ }^{6}$

Until three decades ago, the right to privacy was exclusively afforded to natural persons. The European Court of Human Rights (ECtHR) extended it to legal persons in its judgments in Niemietz ${ }^{7}$ and Colas Est. ${ }^{8}$ Following these ECtHR judgments, the Court of Justice of the European Union (Court of Justice) established, in Roquette Frères, that the right to privacy extends, in certain circumstances, to business premises. ${ }^{9}$ At the same time, the Court of Justice recognized that interference with the right to privacy might be more far-reaching when legal persons are involved, as compared to when natural persons are involved. ${ }^{10}$

Since Roquette Frères, the European Union courts have consistently held that the exercise of the powers of inspection conferred on the Commission by Article 20(4) of Regulation 1/2003 constitutes a clear interference with the right to privacy of inspected companies. ${ }^{11}$

Dawn raids may interfere with the right to privacy at three levels. First, inspections take place at business

3 Pursuant to recital 37 of Regulation 1/2003.

4 The term 'right to privacy' is widely employed in legal literature, where it is generally used to address the rights protected by Article 8 ECHR and Article 7 of the Charter, as a general principle of EU law and as a constitutional right in certain jurisdictions: see E. Suokko, Dawn raids and the right to privacy A comparative study of how the European Convention of Human Rights, the European Union and Finland protect companies' right to privacy in unannounced competition authority inspections (2017), p 23, available at: https://helda.helsinki.fi/handle/10138/228454 (accessed 7 June 2021).

5 Article 7 of the Charter refers to 'communications', while Article 8 ECHR refers to 'correspondence'.

6 See Suokko (fn 4), pp 22-23.

7 Niemietz v. Germany (Application No. 13710/88) [1992] 16 EHRR 97 (ECtHR), para 31.

8 Société Colas Est v. France (Application No. 37971/97) [2003] ECHR-III (ECtHR), para 41.

9 Case C-94/00 Roquette Frères v. Commission EU:C:2002:603, para 29. The European Union courts use different terms to refer to the 'right to privacy'. In Roquette Frères, the Court of Justice referred to this as the 'sphere of private activities of any person, natural or legal'. In Case T-135/09 Nexans France SAS and Nexans SA v. Commission EU:T:2012:596, the General premises and thus interfere with a company's right to respect to the privacy of its private premises. Secondly, inspections may include the seizure of documents, which forms an interference with the right to respect the confidentiality of communications, especially when seized documents are protected under legal professional privilege. Thirdly, without amounting to an interference with a company's own right to privacy per se, the seizure of documents concerning the private lives of that company's employees during an inspection also constitutes an interference with the right to respect the private life of those employees. Subsections 2.2 and 2.3 will explore the circumstances under which these interferences are considered to be justified.

\subsection{The right to privacy and judicial review of inspection decisions}

Interference with the right to privacy is not prohibited as such, provided it: (i) is in accordance with the law; (ii) pursues a legitimate aim of public interest; and (iii) is necessary in a democratic society. As regards the latter criteria, it is essential to determine whether the interference is proportionate (i.e. it is appropriate and necessary to achieve the objective) and not arbitrary (i.e., it is based on circumstances of law or fact capable of justifying the interference). This requires effective safeguards and judicial review. ${ }^{12}$

With regard to the judicial review of the lawfulness of an inspection decision, the General Court held in Czech Railways ${ }^{13}$ and Nexans ${ }^{14}$ that having reasonable grounds for suspecting an infringement of the competition rules is a prerequisite for the Commission to adopt a decision to order an inspection. Failure to have such reasonable grounds of suspicion on the date of the inspection decision

Court referred to a 'right to respect for privacy' and in Joined Cases T-289, 290 and 521/11 Deutsche Bahn v. Commission EU:T:2013:404 to 'the right to the inviolability of private premises'. In Casino (fn 2), reference is also made to the 'right to the inviolability of the home'. See further, Suokko (fn 4), p 23 and fn 129.

$10 \mathrm{H}$. Andersson, Dawn raids under challenge. A study of the European Commission's dawn raid practices in competition cases from a fundamental rights perspective (2017), p 198, available at: http://su.diva-portal.org/ smash/get/diva2:1051228/FULLTEXT01.pdf (accessed 7 June 2021).

11 Deutsche Bahn (fn 9), para 65; and Case T-325/16 České dráhy v. Commission EU:T:2018:368, para 169. The Commission has not disputed that dawn raids form a clear interference with the privacy rights of companies, see Deutsche Bahn (fn 9), para 65.

12 In Deutsche Bahn (fn 9), paras 59-102, it held that the lack of a prior judicial authorization did not in itself make the interference with the applicants' right to privacy unlawful, provided ex post facto in-depth judicial review is available. This was also confirmed by the Court of Justice on appeal: Case C-583/13 P Deutsche Bahn v. Commission EU:C:2015:404, para 35.

13 České dráhy (fn 11), paras 34-36.

14 Nexans (fn 9), para 67. 
amounts to an arbitrary and disproportionate interference with the right to privacy. ${ }^{15}$ As a result, the General Court partially annulled the inspection decisions in Czech Railways and Nexans. As will be explained in Section 3 below, similar considerations formed the basis for the General Court's judgment to partially annul the Commission's inspection decisions in the French supermarkets cases. In these cases, however, the General Court used the term 'sufficiently serious indicia', rather than 'reasonable grounds', for suspecting an infringement.

\subsection{The right to privacy and judicial review of measures taken during a dawn raid}

Although the European Union courts have undertaken judicial review of the lawfulness of inspection decisions under Article 7 of the Charter and Article 8 ECHR, the European Union courts have thus far been reluctant to review, on a standalone basis, potential violations of privacy rights caused by measures taken by the Commission during a dawn raid.

In Nexans,${ }^{16}$ the applicants argued that the Commission had seriously and irreversibly infringed their fundamental rights to privacy and of defence when it copied documents and obtained explanations requested during a dawn raid at their business premises. The General Court considered, however, that it could only review the compatibility of those measures with the applicants' right to privacy and rights of defence, if and when they challenged a final decision adopted by the Commission under Article 7 of Regulation 1/2003 finding an infringement of Articles 101 or 102 TFEU or a decision by the Commission under Article 23(1) (c) or 24(1)(e) of Regulation 1/2003 imposing a penalty for not submitting to an inspection ordered by it. Accordingly, it follows from established case law that copying documents and obtaining explanations are not regarded as standalone actionable measures that are separable from an inspection decision. Although the General Court judgments in the French supermarkets cases do not depart from this approach, the Court does outline the circumstances in which the seizure of documents may nevertheless be subjected to separate and standalone judicial review. This is considered in detail in Section 3 below.

15 Nexans (fn 9), paras 93-94.

16 Nexans (fn 9), paras 119-132.

17 Commission decisions C(2017) 1054 final, C(2017) 1056 final, and C(2017) 1057 final of 9 February 2017 and Commission decision C(2017) 1361 final of 21 February 2017 adopted on the basis of Articles 20(1) and 20(4) of Regulation 1/2003.

\section{The General Court judgments in the French Supermarkets cases}

\subsection{Background}

In February 2017, the Commission conducted unannounced inspections ${ }^{17}$ at the sites of the French supermarket chains Casino, Guichard-Perrachon and its subsidiaries (Casino), Les Mousquetaires and ITM Entreprises (Intermarché), and their joint purchasing vehicle Intermarché Casino Achats (INCA). Pursuant to the operative parts of the Commission's inspection decisions, the subject matter of the inspections was possible participation in concerted practices contrary to Article 101 TFEU involving exchanges of information about: (i) discounts obtained from suppliers and prices for the provision of services to suppliers; and (ii) future business strategies. ${ }^{18}$ The Commission suspected that Casino and Intermarché were coordinating their retail sales activities through their purchasing alliance INCA. In the course of the inspection, the Commission obtained access to offices, interviewed individuals and collected material, including laptops, mobile phones and portable storage devices, and copied the contents of the material. ${ }^{19}$ Casino, INCA and Intermarché objected in writing to the inspection decisions and the inspections that were carried out on that basis. Subsequently, each of them made applications to the General Court for the annulment of the contested inspection decisions. Casino and Intermarché requested the General Court to order the Commission to produce all the documents and other information on the basis of which it considered that it had sufficiently serious evidence to justify an inspection. Additionally, Intermarché claimed that the General Court should annul the Commission's decision to seize and copy private data of its employees as well as the Commission's decision to refuse to return those data.

\subsection{Findings of the General Court}

In the French Supermarkets cases, the applicants challenged, on the basis of the right to privacy, the legality of: (i) the inspection decisions; and (ii) measures taken during the dawn raids. The General Court's findings regarding the application for annulment of the inspection

18 Casino Guichard-Perrachon (fn 2), para 4; Intermarché Casino Achats (fn 2), para 4; and Les Mousquetaires (fn 2), para 4. The three judgments are substantially the same and therefore this article refers to the judgment in Casino Guichard-Perrachon, except where there are differences between the judgments.

19 Casino Guichard-Perrachon (fn 2), para 7 
decision are considered in Section a below and regarding the application for annulment of measures taken during the inspection are considered in Section b below.

\section{a. The compatibility of the inspection decisions with the right to privacy}

The applicants put forward, among other pleas, that the Commission had breached their rights to privacy, in particular the right to the inviolability of the home, as provided by Article 7 of the Charter and Article 8 ECHR. ${ }^{20}$ In the first part of this plea, the applicants argued that the inspection decisions were disproportionate because the Commission had: (i) failed to indicate which companies, premises and persons were subject to inspection; and (ii) omitted to set a time limit for the inspection. ${ }^{21}$ In the second part of this plea, the applicants submitted that the inspection decisions were arbitrary, ${ }^{22}$ as the Commission did not possess sufficient evidence of a potential infringement when the inspection decisions were adopted. The General Court conducted an integral review of each of these points. ${ }^{23}$

\section{aa. How precisely should companies, premises and duration be designated in an inspection decision?}

First, the General Court addressed whether the right to privacy, which protected the applicants from disproportionate interference, requires the Commission to state more precisely the companies and the premises that are subject to the inspection and the duration of the inspection. The General Court concluded that this was not required in the present case. According to the General Court, the applicants could have derived from the inspection decisions the companies and premises that were subject to the inspections, because the subject matter, the purpose and the relevant markets were indicated in the decision. ${ }^{24}$ Specifications that are more precise were not required. ${ }^{25}$ The General Court further noted that Article 20(4) of Regulation 1/2003 only requires the Commission to provide, in an inspection decision, the date on which the inspection commences and not the end date. The duration of an inspection should however not exceed 'a reasonable time limit in accordance with Article 41(1) of the Charter. ${ }^{26}$ The judgments suggest that a different conclusion may have been reached if the inspections had been carried out under force, i.e. without the applicants' cooperation. ${ }^{27}$

\section{bb. What constitutes 'sufficiently serious evidence' to justify an inspection?}

The General Court also examined whether the inspection decisions were arbitrary and breached the applicants' right to privacy due to lack of sufficiently serious evidence to suspect an infringement. ${ }^{28}$

Following a request made by the General Court, the Commission produced the following documents upon which it had based the inspection decisions:

- minutes of interviews it held with 13 suppliers;

- emails establishing the dates of those interviews;

- an email from a suppliers' trade organization, together with several annexes, including a presentation of the Intermarché convention held in September 2016; and

- analytical presentations that contained indicia of the two suspected infringements related to: (i) information exchanges regarding discounts on the supply markets; and (ii) information exchanges regarding future commercial strategies. ${ }^{29}$

Before conducting a material assessment of these documents, the General Court recalled that it is not required to assess whether the Commission had evidence capable of establishing the existence of an infringement. Instead, the General Court considered that it is only required to assess whether the Commission had sufficiently serious evidence capable of creating a suspicion of an infringement. ${ }^{30}$ In other words, the Commission is (only) required to have some form of probable cause in order to be able to initiate inspections.

The General Court further held that the distinction between the two levels of proof $^{31}$ has implications for the requirements relating to the form, the author and the content of the evidence needed to justify an inspection
20 Casino Guichard-Perrachon (fn 2), paras 121-128; Intermarché Casino Achats (fn 2), paras 141-151; and Les Mousquetaires (fn 2), paras 148-154.

21 Casino Guichard-Perrachon (fn 2), paras 131, 132, 149 and 158.

22 Casino Guichard-Perrachon (fn 2), paras 164-274.

23 Casino Guichard-Perrachon (fn 2), paras 127 and 166

24 On that basis Casino was able to ascertain that the Casino companies that are active in the: (i) supply of fast-moving consumer goods (food products, hygiene products and cleaning products); (ii) the markets for consumer sales of those goods; and (iii) the market for the sale of services to manufacturers of branded products in the fast moving consumer goods sector, were targeted by the decision.

25 Casino Guichard-Perrachon (fn 2), para 144

26 Casino Guichard-Perrachon (fn 2), para 152
7 Casino Guichard-Perrachon (fn 2), paras 147 and 156.

28 Casino Guichard-Perrachon (fn 2), para 165. See also Case T-402/13 Orange v. Commission EU:T:2014:991, paras 82-84.

29 Casino Guichard-Perrachon (fn 2), para 169

30 Casino Guichard-Perrachon (fn 2), para 183. In Nexans (fn 9), Orange (fn 28) and České dráhy (fn 11), the General Court used the term 'reasonable grounds' for suspecting an infringement, instead of 'sufficiently serious indicia'. See also Roquette Frères (fn 9), para 54; Nexans, para 43, Orange, para 84; and České dráhy (fn 11), para 36.

31 Evidence establishing an actual infringement on the one hand and evidence creating a suspicion of an infringement to initiate an investigation on the other hand. 
decision. ${ }^{32}$ These implications are described in more detail below.

(a) No requirement for interviews to be recorded or transcribed to constitute sufficiently serious indicia

First, the General Court held that the evidence underpinning an inspection decision could include written and oral accusations made in a written complaint, an (oral) leniency application or (oral) witness interviews. ${ }^{33}$

The applicants argued that the 13 oral interviews relied upon by the Commission were vitiated by a formal irregularity because they were not recorded. The General Court dismissed this argument and held that the obligation to record interviews does not apply to interviews conducted before the start of an investigation. ${ }^{34}$

Additionally, the applicants argued that the 13 interviews were not in the Commission's possession when the inspection decisions were adopted, because the Commission did not establish the date of the minutes of those interviews. The General Court also rejected that argument, holding that the 'possession' of evidence is equivalent to knowledge of its content. ${ }^{35}$ Accordingly, the Commission was in possession of the indicia emerging from those interviews on the date those interviews took place, and not when the oral interviews were transcribed. ${ }^{36}$ Those interviews took place before the adoption of the inspection decisions, as was established by emails and diary entries ${ }^{37}$ of the Commission officials, which contained appointments for interviews with the relevant parties. ${ }^{38}$

It follows that interviews do not need to be recorded or transcribed into minutes in order for the Commission to rely on them, provided that it can be demonstrated that those interviews took place before the decision. That being said, the content of those interviews can be demonstrated by minutes prepared at a later stage.

\section{(b) Statements of third parties may constitute sufficiently serious indicia}

Secondly, as regards the author of the indicia, the General Court held that the criteria established in the case law for the assessment of the credibility of evidence constituting proof of an infringement - such as the origin of the evidence, the circumstances in which it was created, the person addressed by the evidence, the soundness and reliability of its content and whether it was drawn up by direct witnesses to the event ${ }^{39}$ - cannot be applied in the same way to indicia supporting an inspection decision. Such indicia often come from third parties with no (direct) participation in the suspected unlawful conduct, such as competitors of the company under investigation, parties that have suffered harm as a result of the conduct, public or private entities (such as competition authorities and experts) and suppliers that are in a commercial relationship with the undertaking being investigated. ${ }^{40}$ Therefore, the assessment of indicia that justify an inspection is different, as compared to the assessment of evidence of an infringement.

The indicia in the present case originated from the applicants' suppliers. The General Court acknowledged that, although the suppliers may have an interest to see the applicants being penalized, the suppliers nevertheless had direct knowledge of the effects of the suspected unlawful conduct. Hence, according to the General Court, the caution that should normally be exercised when interpreting accusations made by parties that are interested in seeing the suspected undertaking fined, applies to a lesser extent to statements made by suppliers, in particular where the suppliers state specific facts derived from their business relationships with the undertaking suspected of infringing competition law. ${ }^{41}$

\section{(c) The standard of 'sufficiently serious indicia justifying inspections' is lower than the standard of proof for find- ing a concerted practice}

Thirdly, the General Court established that the threshold at which the Commission has sufficiently serious indicia to justify commencing an investigation of a suspected concerted practice is lower than the threshold for proving a concerted practice. ${ }^{42}$

This is a consequence of the fact that the Commission's burden of proving the three components of a concerted practice (i.e., (i) collusion, (ii) market conduct, and (iii) a relationship of cause and effect between the market conduct and the collusion ${ }^{43}$ ) has been alleviated to compensate for the fact that evidence of a concerted practice is fragmentary and sparse. Furthermore, the General Court held that evidence that is open to different interpretations can still form sufficiently serious indicia if the interpretation of the Commission is plausible. ${ }^{44}$
32 Casino Guichard-Perrachon (fn 2), paras 183-185.

33 Casino Guichard-Perrachon (fn 2), paras 188-189.

4 Casino Guichard-Perrachon (fn 2), para 193.

35 Casino Guichard-Perrachon (fn 2), paras 201-202.

3 Casino Guichard-Perrachon (fn 2), paras 200-201.

7 Casino Guichard-Perrachon (fn 2), para 209.

38 Casino Guichard-Perrachon (fn 2), para 205.
39 Casino Guichard-Perrachon (fn 2), para 213 and case law referred to.

40 Casino Guichard-Perrachon (fn 2), paras 214-216.

41 Casino Guichard-Perrachon (fn 2), para 217.

42 Casino Guichard-Perrachon (fn 2), para 230.

43 Casino Guichard-Perrachon (fn 2), para 224.

44 Casino Guichard-Perrachon (fn 2), para 222. 
cc. The General Court's assessment of the indicia relied upon by the Commission in relation to the exchange of information regarding discounts of suppliers

Regarding the first suspected infringement - exchanges of information about discounts and prices on the supply markets - the General Court found that before adopting the inspection decisions the Commission had possessed sufficiently serious indicia of potential parallel conduct. ${ }^{45}$

The Commission's evidence of parallel conduct consisted of suppliers' statements describing in detail receipt of similar or identical requests for discounts. ${ }^{46}$ Furthermore, the Commission had evidence of collusion through information exchanges between the applicants (although these were sometimes vague or speculative ${ }^{47}$ ) which, taken as a whole, also constituted sufficiently serious indicia. ${ }^{48}$ The General Court concluded that the indicia relied on by the Commission provided no plausible alternative explanation for parallel behaviour other than underlying collusion or concertation. ${ }^{49}$

In addition to those indicia, the General Court considered that: (i) none of the suppliers had considered it unlikely that parallel behaviour was the result of an exchange of information; ${ }^{50}$ (ii) the one supplier that argued that parallel behaviour could have been the result of bluffing by some of the distributors, had less information than others and therefore did not provide a plausible alternative explanation, ${ }^{51}$ and (iii) supporting information about the channels through which information may have been exchanged made the existence of an illicit exchange of information plausible. ${ }^{52}$

Although the Commission's information did not derive from direct witnesses and may have been speculative, the General Court considered that the multiplicity, precision and consistency of the information taken as a whole, compensated for the speculative nature of the information. ${ }^{53}$ The General Court therefore concluded that the Commission had had sufficiently serious indicia of the first alleged infringement to adopt the inspection decisions. dd. The General Court's assessment of the indicia relied upon by the Commission in relation to the exchange of information regarding future business strategies

For the second suspected infringement concerning the exchange of information about future business strategies, the Commission based its inspection decisions (mainly) on one indicium; i.e. the Intermarché convention of 21 September $2016 .{ }^{54}$

The Intermarché convention was attended by suppliers as well as a director of Casino. ${ }^{55}$ At the convention, Intermarché presented its commercial priorities relating to its product range, e-commerce and promotional practices. ${ }^{56}$

The Commission considered that this was an indication that Intermarché had shared commercially sensitive information concerning its future business strategies with Casino.

The General Court, however, found that the mere presence of the Casino director, in the circumstances at hand, did not provide evidence of a potential concerted practice. ${ }^{57}$ The Casino director attended in his capacity as managing director of INCA, the joint purchasing vehicle of Casino and Intermarché.

Furthermore, the fact that the director was under strict confidentiality obligations vis-à-vis Casino added to the General Court's conviction that his attendance did not provide evidence for founding a reasonable suspicion of a concerted practice, at least not without corroborating evidence that Casino had in fact received the information provided during the convention. ${ }^{58}$

In addition, and more generally, the General Court found that the information that was exchanged at the convention qualified as genuinely public information: ${ }^{59}$ the information was conveyed in the presence of over 400 suppliers. In addition, journalists were present and reported about the convention in detailed press reports. ${ }^{60}$ As to the possibility that Intermarché had orchestrated a concerted practice by making unilateral public announcements (signalling), the General Court simply added that the Commission had not asserted this in the inspection decisions, nor had it argued that
45 Casino Guichard-Perrachon (fn 2), para 241.

46 Casino Guichard-Perrachon (fn 2), para 242.

47 Casino Guichard-Perrachon (fn 2), para 244.

48 Casino Guichard-Perrachon (fn 2), para 243.

49 Casino Guichard-Perrachon (fn 2), para 246.

50 Casino Guichard-Perrachon (fn 2), para 245.

51 Casino Guichard-Perrachon (fn 2), para 246.

52 Casino Guichard-Perrachon (fn 2), paras 247-248 (movements between distributor alliances, transfers of retail chains, a joint subsidiary by Intermarché and Casino and exchanges of staff which could have led to an exchange of information regarding discounts obtained by competing distributors).

53 Casino Guichard-Perrachon (fn 2), paras 249-250.

54 Casino Guichard-Perrachon (fn 2), paras 252-253.

55 Casino Guichard-Perrachon (fn 2), para 259.

56 Casino Guichard-Perrachon (fn 2), para 254

57 Casino Guichard-Perrachon (fn 2), para 259.

58 Casino Guichard-Perrachon (fn 2), paras 259-260.

59 Casino Guichard-Perrachon (fn 2), paras 265-267.

60 Casino Guichard-Perrachon (fn 2), para 263. 
it had suspected a signalling violation during the proceedings. ${ }^{61}$

Based on the above, the General Court concluded that the Commission did not have sufficiently serious indicia that could justify an inspection of the second suspected infringement. ${ }^{62}$ The Commission, therefore, violated the applicants' right to privacy ${ }^{63}$ and the General Court annulled the inspection decisions in so far as they concerned the second infringement. ${ }^{64}$

\section{ee. Access to the indicia supporting an inspection decision}

An issue that arises when applicants wish to appeal an inspection decision on the ground of lack of sufficiently serious indicia is that those indicia are usually unknown to the applicants. The Commission is only obliged to mention in the inspection decision that it possesses indicia, without having to produce the indicia during the inspection. In the present case, the applicants requested the General Court to adopt a measure of organization of procedure ${ }^{65}$ to compel the Commission to produce the indicia. ${ }^{66}$ The General Court allowed the request and ordered the Commission to produce a non-confidential version of the indicia in court. The judgments suggest that, in the course of the proceedings, the applicants also requested access to a confidential version of the indicia. However, the Commission requested the court to restrict access to the confidential version of the indicia to the applicants' external counsel only and on the condition that the confidential version should not be disclosed to the applicants. The applicants' counsel, objected to this proposal of a 'confidentiality ring' and proposed a number of alternative forms of access and requested the General Court to hold an informal meeting for further discussions. ${ }^{67}$

The General Court subsequently requested the Commission to answer several questions on which the applicants could file observations. ${ }^{68}$ It seems to transpire from the judgment that, ultimately, no confidential version of the indicia were produced, not even into a confidentiality ring. ${ }^{69}$

Disclosure of the confidential version of the indicia may not have been needed in the present case, because the non-confidential version of the indicia may have already been fairly elaborate, as the indicia relied upon by the Commission did not include (confidential) leniency statements. The question remains whether the General Court would have required leniency statements to be produced into a confidentiality ring if the indicia relied on by the Commission had included leniency statements.

The English Court of Appeal dealt with a comparable question in Competition and Markets Authority v. Concordia, where it had to review the grant of a warrant to the Competition and Market Authority (CMA) that was based on material subject to 'public interest immunity' (PII). Concordia argued in its appeal that the material subject to PII should be disclosed into a confidentiality ring comprised of its external counsel. ${ }^{70}$ The Court of Appeal, however, dismissed that argument and held that PII material can only be reviewed by the court by way of a closed material procedure and not by the company subject to the warrant. It therefore dismissed the possibility of setting up a confidentiality ring for PII material. ${ }^{71}$

It seems that the Court of Appeal considered in this regard that the interference with the rights of defence is justified in such cases, as the public interest of enforcement at such an early stage of the investigation outweighs the interests of the applicant.

\section{b. The right to privacy and limits to the seizure of documents}

Intermarché requested the General Court to annul the decisions adopted by the Commission to seize and copy documents containing information concerning the private lives of its employees and to refuse the return of those documents.

This form of order sought by Intermarché raises two interesting questions:

- Do inspected companies have an interest in challenging the seizure of documents by the Commission based on a claim for the protection of the private lives of their employees?

- Is judicial review available against the seizure of documents containing private information in the course of a dawn raid?

On the first question the General Court confirmed that inspected companies do have such interest and that a
61 Casino Guichard-Perrachon (fn 2), para 269.

62 Casino Guichard-Perrachon (fn 2), para 273.

63 Casino Guichard-Perrachon (fn 2), para 274.

64 Casino Guichard-Perrachon (fn 2), para 275.

65 On the basis of Article 98(3)(d) of the Rules of Procedure of the General Court [2015] O.J. 2015 L 105/1.

66 Casino Guichard-Perrachon (fn 2), para 11.
67 Casino Guichard-Perrachon (fn 2), paras 15-16.

68 Casino Guichard-Perrachon (fn 2), para 17.

69 Casino Guichard-Perrachon (fn 2), para 271.

70 Competition and Markets Authority v. Concordia International RX (UK) [2018] EWCA Civ 1881, para 4.

71 CMA v. Concordia (fn 70), para 74 
claim for protection of information pertaining to the private lives of employees is not exclusively restricted to the relevant employees. As companies are under a legal obligation to protect their employees' interests, including their right to privacy, ${ }^{72}$ companies have a legitimate interest to prevent a threatened infringement of their employees' rights to privacy.

On the second question, the General Court followed its previous judgment in Nexans ${ }^{73}$ and held that the seizure of documents in the course of an inspection is not a legal act that produces legal effects separately from a final decision establishing a competition law infringement. Nevertheless, the General Court did not entirely rule out the possibility that the seizure of documents may be subject to stand-alone judicial review. This might be possible when the seizure gives rise to the adoption of a decision with legal effects, e.g. when the seizure takes place after an inspected company made a clear and precise request for protection on grounds of privacy (i.e., a privacy claim). As Intermarché failed to make a privacy claim before the Commission seized the documents containing private information, there was no decision open to challenge. Therefore, the General Court declared Intermarchés application to be inadmissible. $^{74}$

According to the General Court, Intermarché's request for return of those documents also did not give rise to a challengeable decision. Intermarché's request was not sufficiently precise to enable the Commission to define its position (in the form of a decision). ${ }^{75}$ Intermarché had not identified any specific documents. It had made only general references to 'personal messages, address books, telephone conversations' without pinpointing any in particular.

\section{Practical significance of the General Court's judgments}

\subsection{The importance for Commission inspection decisions to be based on sufficiently serious indicia}

The General Court judgments in the French supermarkets cases confirm that although the Commission's inspection

2 Les Mousquetaires (fn 2), para 32

73 Nexans (fn 2), para 126.

74 Les Mousquetaires (fn 2), para 40.

75 This is one of the remedies that the General Court examines when assessing whether companies subject to an inspection have effective remedies at their disposal. The General Court considered that the following remedies taken as a whole are effective remedies of judicial review: (1) an action for annulment against the final decision closing the procedure under Article 101 TFEU; (2) an action for annulment against the inspection decision; (3) an action for annulment against a sanction decision on the basis of powers are broad, the Commission does not have a 'carte blanche' to undertake investigations at will. Having strong evidence (i.e., sufficiently serious indicia) to suspect an infringement is a prerequisite for the Commission to use its investigatory powers based on its large margin of discretion. This is the outcome of the balancing act between the level of interference with a company's right to privacy and the need for the Commission to effectively investigate possible infringements of competition law. However, when it is apparent that the Commission does not possess strong evidence to suspect an infringement before adopting an inspection decision, the inspection decision will be considered as a disproportionate and arbitrary interference with the inspected company's right to privacy and the General Court will not hesitate to annul the inspection decision, whether in whole or part. In fact, the General Court will review in-depth whether the Commission's evidence justified an inspection decision, which is in line with the requirements of Article 8 ECHR and Article 7 of the Charter. Therefore, the operational part of inspection decisions should be closely reviewed by companies and their lawyers.

It follows from the case law of the General Court that, even though the Commission is not required to provide the legal qualification of the alleged infringement, a precise market delineation, the exact period of the suspected infringement ${ }^{76}$ or the indicia in its possession, ${ }^{77}$ the Commission is nevertheless required to provide at least the following information in an inspection decision:

- a description of the presumed facts it intends to investigate, which should be as precise as possible;

- the features of the alleged infringement under investigation;

- the alleged affected market;

- the sectors covered by the alleged infringement;

- the nature of the alleged infringement; and

- an explanation of how the investigated company is considered to be involved. ${ }^{78}$

Differences between the subject matter and purpose of an inspection decision, on the one hand, and the scope of the inspection actually carried out, on the other, could be an indication that the Commission did not have sufficiently serious indicia for one (or more) of the suspected infringements.

Article 23(1)(c)-(e) of Regulation 1/2003; (4) an action for annulment of a decision rejecting an application for protection of documents covered by legal professional privilege; (5) an application for interim relief; and (6) an action for non-contractual liability: Casino Guichard-Perrachon (fn 2), paras 56-67.

76 České dráhy (fn 11), para 126.

77 Casino Guichard-Perrachon (fn 2), paras 107 and 112. See also České dráhy (fn 11), para 38.

78 Casino Guichard-Perrachon (fn 2), para 110 and České dráhy (fn 11), para 39. 
From a company's perspective it may be advantageous in some cases to file an appeal against an inspection decision, in particular if there is sufficient concern that the Commission's evidence might be thin. It may therefore be a way to prevent the Commission from investigating matters further where it lacks sufficiently serious indicia. Alternatively, it may be a way to get a first view of the evidence in the Commission's possession at a relatively early stage in the proceedings (i.e., before the investigation proceedings are formally initiated or before the statement of objections is notified by the Commission).

\subsection{The different legal and evidentiary standards applicable to evidence justifying an inspection}

The Commission must possess sufficiently serious indicia regarding all elements of the suspected infringement under investigation and which is covered by the inspection decision Those indicia can be derived from various sources (including oral and written accusations made by third parties, such as suppliers, customers and competitors), do not need to meet the same formal legal requirements of evidence to prove an actual infringement, and may be open to multiple interpretations. That being said, the indicia must at least be able to support a plausible theory of harm that warrants further investigation by the Commission. When it comes to suspected concerted practices, the indicia must reveal that the exchanged information was in fact received by the other participants and that the exchanged information was not genuinely public information.

\subsection{The importance of making timely and clear privacy claims}

Inspected companies and their lawyers should ensure they raise, in a timely fashion, clear and precise objections against the seizure of documents by the Commission that contain private information of their employees or managers. In addition, inspected companies should ensure that requests for the return of private documents after they have been seized are both precise and specific.

Although there is no case law yet confirming the admissibility of an action before the General Court challenging a decision by the Commission rejecting a request to protect documents containing information on the private lives of employees of the inspected company, the General Court recognized that such an action is not precluded by the TFEU or Regulation 1/2003. In other words, it seems that the General Court has opened the door for raided companies to challenge the seizure of private and sensitive information about their employees. However, this door only seems to be open when a raided company immediately makes a privacy claim while an inspection is in progress and before any privacy sensitive information has been copied. This approach may be regarded as restrictive if it means that a privacy claim made after a dawn raid is completed is not capable of giving rise to an (implicit) rejection decision that produces legal effects and is open to challenge before the General Court. In our view, the seizure and copying of private documents should be subject to judicial review regardless of the timing of the privacy claim, provided the private documents and privacy objections are clearly identified. Otherwise, the General Court not only limits the possibility for applicants to seek annulment of the measure in question, but also the possibility for applicants to seek interim relief to prevent the Commission from reviewing and using those documents. ${ }^{79}$ In view of the General Court's current approach, the only remedy available to an applicant that makes a privacy claim after a dawn raid would be an action for non-contractual liability under Article 340 TFEU. In that regard, an applicant would need to demonstrate that it has suffered harm due to the seizure and review of documents containing private information of its employees. Evidence of harm may be difficult to provide, because while the company has a legal obligation to protect the privacy of its employees it is not the owner of the private information seized by the Commission and therefore not the one directly suffering harm. ${ }^{80}$

\section{Closing remarks}

It remains to be seen what impact the judgments in the French Supermarkets cases will have on the outcome of new inspections carried out by the Commission at the premises of Casino and Intermarché in May and July 2019 and the subsequent formal antitrust proceedings initiated by it in November $2019 .{ }^{81}$ Casino and Intermarché have each already submitted an application for annulment of the inspection decisions of May and July 2019 to the extent that they were adopted on the
79 Andersson (fn 10), p 374.

80 See also Case T-451/20 R Facebook Ireland Ltd. v. Commission EU: $\mathrm{T}: 2020: 515$, para 113
81 Case AT.40466 Alliance Casino \& Intermarché; see Commission press release, Antitrust: Commission opens investigation into possible collusion by two French retailers in a purchasing alliance (IP/19/6216, 4 November 2019). 
basis of documents obtained during the inspections carried out in February 2017, ${ }^{82}$ which are the subject of the judgments discussed in this article.

It also remains to be seen how the Commission will deal with privacy claims made in relation to documents seized during an inspection and whether it will introduce a standard procedure, similar to the Privacy Protocol ${ }^{83}$ that the Irish Competition and Consumer Protection Commission (CCPC) introduced for dealing with such privacy claims in 2018 in the aftermath of the judgment of the Irish Supreme Court in Irish Cement. ${ }^{84}$ In that case, Irish Cement sought interim relief to prevent the review of certain electronic files within the mailbox of one of its senior executives. The Supreme Court held that if the CCPC were to proceed with the review of those files that would constitute a breach of Irish Cement's rights to privacy. The Supreme Court also held that the CCPC should consider developing a code of practice, which it did and resulted in the Privacy Protocol.

While the General Court did not hold in the French Supermarkets cases that the Commission should consider developing such a procedure, the General Court did require the Commission to do this in its recent orders in the Facebook cases. ${ }^{85}$ Following an application for interim measures by Facebook, the General Court suspended Facebook's obligation to disclose documents not linked to its business activities and containing sensitive personal data in response to a Commission request for information (RFI). The General Court ordered the Commission to put in place an ad hoc procedure for the examination of documents likely to contain sensitive personal data. ${ }^{86}$ The procedure ordered, described in detail, by the General Court involved inter alia the placement of contested documents in a virtual data room, that they could be reviewed by a limited number of Commission officials and for disagreements about the classification of documents to be settled by the Director for Information, Communication and Media at DG Competition. This could become the blueprint for a more permanent procedure to review privacy claims in competition cases in the near future.
82 Case C-693/20 P Intermarché Casino Achats v. Commission and Casino; Case C-690/20 P Guichard-Perrachon and Achats Marchandises Casino v. Commission.

83 Competition and Consumer Protection Commission, 'Protocol for dealing with claims of privacy rights in connection with unannounced searches conducted on foot of a search warrant under section 36 or section 37 of the Competition and Consumer Protection Act 2014' (1 June 2018), available at: https://www.ccpc.ie/business/wp-content/uploads/sites/3/ 2018/06/Privacy-Protocol.pdf (accessed 7 June 2021).

84 CRH plc and Irish Cement Ltd v. The Competition and Consumer Protection Commission [2017] IESC 34, Irish Supreme Court.

85 Facebook Ireland (fn 80); and Case T-452/20 R Facebook Ireland Ltd. v. Commission EU:T:2020:516.

86 Facebook Ireland (fn 80), paras 119-120. 